\title{
THE ATTITUDINAL MEANING BUILT BY KONDE.CO REGARDING THE RATIFICATION OF CHEMICAL CASTRATION PENALTY
}

\author{
Hidayatul Mahmudah, Harni Kartika Ningsih \\ Universitas Indonesia, Depok, Indonesia \\ E-mail: hidayatulmahmudah97@gmail.com
}

Received: 2021-11-09

Accepted: 2021-11-29

\begin{abstract}
The rise of sexual violence against women and children encourages the government to establish Government Regulation (Peraturan Pemerintah) hereafter (PP) number 70 of 2020, which contains the application of the chemical castration penalty for the offenders of sexual violence. This regulation causes pros and cons from the various parties, including women and children's observer community, selected in this case Konde.co. This study aims to discuss the Attitude or position built by Konde.co toward the Government Regulation (PP) ratification concerning the chemical castration penalty for the sexual violence offenders. This research uses a qualitative approach, especially discourse analysis. The discourse analysis in this research uses the appraisal theory, which studies the Attitude system explicitly The result of this research shows that the Attitude that appears in the text is generally negative. Furthermore, the Attitude aspect with the highest frequency is negative judgement. The negative Attitude refers to the incompatibility and inability of the chemical castration penalty in overcoming the sexual violence problem in Indonesia. The chemical castration penalty has negative impacts, such as exacerbating sexual violence in Indonesia in the future, disturbing, like an inclement regulation, and violating human rights. The positive Attitude refers to the PP's capacity for the chemical castration penalty of the sexual violence offenders in upholding the rights of the underprivileged. Other priorities that Konde.co considers more critical in overcoming the sexual violence problem are the recovery of the victims and the immediate ratification of the Bill on the Elimination of Sexual Violence.
\end{abstract}

Keywords: Appraisal, Sexual Violence, Chemical Castration Penalty

\section{Introduction}

The sexual violence case in Indonesia is still high, the sexual violence case mainly occured to women and children, registered in 2020, raised from the years before. Based on the Women's National Commission (Komnas Perempuan) annual record in 2020, 431.471 cases of violence against women registered are reported and handled, this number of cases raised to $6 \%$ from the year before. The Women's National Commission (Komnas Perempuan) also recorded that in 12 years, the violence against women raised to $792 \%$, which means the violence against women in Indonesia in 12 years increased almost 8 times (Komnas Perempuan, 2020). According to the data from the Ministry of Women Empowerment and Children Protection (Kementerian Pemberdayaan Perempuan dan Perlindungan Anak), from 
The Attitudinal Meaning Built by Konde.Co Regarding The Ratification of Chemical Castration Penalty, Hidayatul Mahmudah, Harni Kartika Ningsih

the 1st January to 19th June 2020, there were reported 3.087 cases of violence against children, including 852 physical violence cases, 768 physicist violence cases, and 1.848 sexual violence cases (Kementerian PPPA, 2020).

To overcome this high number of sexual violence cases, the government established Government Regulation (Peraturan Pemerintah) hereafter (PP) Number 70 concerning procedures for implementing chemical castration, installing electronic detection devices, rehabilitation, and announcing the identity of offenders of sexual violence against children. The President signed this PP on December 7, 2020 (Dharmastuti in detik.com, 2021). The enactment of the PP related to chemical castration for offenders of sexual violence has drawn pros and cons from various parties, including women's activists and observers of women and children's issues. One of them is Konde.co.

Konde.co is a media that focuses on women and minorities perspectives, and the work scope is in publishing articles on the website, producing a movie or video, and giving the public information through social media, such as Facebook, Instagram, and Twitter, regarding women and minorities' problems (Konde.co, n.d.). Konde.co formed in 2016 that was managed by individuals who have the same perspective in perceiving women and minorities. Konde.co's establishment purposes to manage public space from the perspective of women and minorities as part of the critical power awareness (Konde.co, n.d.). On its website, many articles highlight various problems of women and minorities with critical views, including the sexual violence issues that are rife against women and children.

Regarding the issue that is currently as a public discussion, namely the ratification of the Government Regulation (PP) on chemical castration procedures for sexual offenders, Konde.co as a media that is focused on the perspectives of women and minorities, also highlighted this case, which can be seen through the posting articles on its official website. It was interesting to see Konde.co' Attitude as a media that moved on a critical view of women and minorities towards the ratification of the PP on chemical castration for offenders of sexual violence. Linguistically, to see Konde.co's Attitude, this case could be studied through appraisal theory.

The appraisal is a framework for analyzing the interpersonal systems in semantic discourse from systemic functional linguistics (Martin \& White, 2005). Pérez (2019) states that the appraisal system is a part of the linguistic analysis model in systemic linguistics. The language is described as a whole network of interconnected systems and allows speakers to express meaning. Appraisal theory is the development of Halliday's Functional Grammar theory of interpersonal meaning. This appraisal theory is an analytical device within the scope of discourse analysis that emphasizes the readers' position of a text with three main domains, which are (1) engagement, (2) Attitude, and (3) graduation, each of which becomes a single unit to analyze interpersonal meaning in one text (Martin \& White, 2005). Stosic (2021) mentions the benefits of using appraisal in discourse analysis based on the fact that, (1) the appraisal is a well-established analytical framework (has a systematic annotation scheme) that is included in the broader SFL theory to detail the interrelationships between texts and social contexts, (2) Aspects of engagement, Attitude, and graduation can be adjusted in terms of the analysis purpose, (3) the appraisal can distinguish between implicit and explicit Attitudes.

This research focuses on the appraisal system, especially the Attitude aspect on Konde.co concerning the Government Regulation (PP) ratification Number 70 of 2020 regarding the implementation of chemical castration for the sexual violence' offenders. This research aims to describe the Attitude or position built by Konde.co towards the ratification 
of the chemical castration penalty for the sexual violence offenders. The benefit of this research can be to see the perspective of the media or community of women and minorities observers toward government policies related to chemical castration for the sexual violence' offenders. This research can also contribute to considering the government in passing regulations regarding the punishment for sexual violence offenders by considering the perspectives of women and minorities.

\section{Literature Review}

The appraisal system analysis in this research refers to Martin \& White (2005), focusing on the Attitude aspect. Martin \& White (2005) mentions that Attitude describes how a writer or speaker evaluates something, including the expression of the speaker's/writer's feelings, emotional reactions, an assessment of a person's Attitude and evaluation of something. This assessment is both positive and negative. Attitude consists of three aspects, namely, affect, judgement, and appreciation (Martin \& White, 2005). Affect relates to emotional responses towards something, such as sadness, joy, hatred, etc. Affect consists of un/happiness, in/security, and dis/satisfaction (Martin \& White, 2005). The judgement relates to positive or negative judgments, such as praising, criticizing, blaming, or admiring (Martin \& White, 2005). Judgment is divided into five aspects: normality, capacity, tenacity, veracity, and propriety. Appreciation relates to the assessment of natural phenomena that are aesthetic. Appreciation is divided into reaction, composition, and valuation (Martin \& White, 2005)).

Previously, Indrayani (2019) had performed research related to the appraisal system on the discourse of sexual violence, which examined victims of sexual harassment represented in news texts and readers' Attitudes in responding to the news text. The analysis used transitivity to see the representation of sexual harassment victims in the text, appraisal analysis, mainly on the Attitude aspect, to see the reader's Attitude, and reception analysis to see the reader's acceptance. The research results showed the sexual harassment victims described by Detik.com, especially on the news of sexual harassment by Baiq Nuril, declared as a victim of verbal abuse. Attitudes that are appeared in the reader's comment box tended to show negative judgment. The reception that was found most in the reader's comment box was the negotiated position. Zamzuardi \& Syahrul (2019) had also performed research regarding the sexual violence discourse on the news with a critical discourse analysis approach of Sara Mills, a model. The findings revealed that women were visually dominant in the news while underrepresented in terms of meaning. Suprihatin and Lestari (2019) also conducted research related to the discourse of sexual violence in the news, especially on Tirto.id with a critical discourse analysis approach of Norman Fairclough, a model. The results showed that based on lexical and grammatical textual analysis, Tirto.id used supportive vocabulary towards victims and survivors of sexual violence and chose vocabulary with negative connotations aimed at the sexual violence offenders. Tirto.id also used active sentences to emphasize the presence of sexual violence actors from the text.

The study in this research differs from the previous ones in twofold. First it focuses on the news outlet specifically engaged in women and minorities perspectives. Secondly, the issue is to do with the offenders instead of the victims. That is the legalization of the use of a chemical castration penalty for sexual violence offenders. This heated topic is currently a public concern and has raised pros and cons in the public sphere. 
The Attitudinal Meaning Built by Konde.Co Regarding The Ratification of Chemical Castration Penalty, Hidayatul Mahmudah, Harni Kartika Ningsih

\section{Research Method}

This research uses a qualitative approach. A qualitative approach is an approach that explores and understands the social problems or human problems and creates significant interpretations of the data (Creswell and Creswell, 2018). The data in this research are clauses that contain the Attitude or position that Konde.co builds towards the Government Regulation (PP) regarding the chemical castration penalty to the sexual violence offenders. This research's data source comes from the articles posted on the Konde.co website with the topic of ratifying the (PP) concerning the chemical castration penalty for the sexual violence offenders, eight articles in total.

The method used to collect the data is listening with a note-taking technique (Sudaryanto, 2015). At this point, the listening method is performed by carefully listening or reading the data, which are the clauses that contain Konde.co's Attitude in ratifying the (PP) regarding the chemical castration penalty for the sexual violence offenders. In addition, the data are recorded by using Microsoft Word and the annotation on the data performed based on the aspects of the appraisal device, especially on the Attitude aspect, which afterward, the data is transferred into a txt form and inputted into the data processing device.

This research uses the linguistics corpus method in processing the data. The linguistics corpus method implicates text collection analysis that saves electronically in a large number, assisted by computer software (Baker, 2010). This research uses LancsBox software. LancsBox used to be a data processing device in this research since this software provides convenience in identifying the annotated text. Furthermore, the features provided can be used to observe the frequency of the data shown, the context of use, and data visualization. This frequency calculation is used to compute the data occurrences percentage and the subappraisal Attitude tendency that appears in the data, leading to a description of the use Attitude pattern at Konde.co regarding the (PP) of chemical castration approval.

The data analysis in this research uses appraisal system theory (Martin and White, 2005), especially in the sub-appraisal Attitude consisting of affect, judgement, and appreciation. Attitude used is to reveal Konde.co's Attitude in ratifying the Government Regulation (PP) regarding the chemical castration penalty for the sexual violence offenders. In conclusion, the analysis result is presented with the informal presentation method (Sudaryanto, 2015), which is the formulation and decomposition in words.

\section{Results and Discussion}

This research focuses on the appraisal system analysis, specifically on the Attitude aspect based on the theory of Martin and White (2005). The appraisal system, especially the Attitude aspect, is identified based on three aspects, namely affect, judgment, and appreciation. The details of the Attitude aspect are listed in table 1 as follows.

\begin{tabular}{|l|l|c|c|c|}
\hline Number & Attitude & Aspect & Frequency & \% \\
\hline \multirow{3}{*}{1} & \multirow{2}{*}{ affect } & un/happiness & 0 & $0.00 \%$ \\
\cline { 3 - 5 } & & in/security & 8 & $7.92 \%$ \\
\cline { 3 - 5 } & & dis/satisfaction & 0 & $0.00 \%$ \\
\hline \multirow{3}{*}{2} & judgement & Normality & 4 & $3.96 \%$ \\
\cline { 3 - 5 } & & Capacity & 38 & $37.62 \%$ \\
\cline { 3 - 5 } & & Tenacity & 12 & $11.88 \%$ \\
\cline { 3 - 5 } & & Veracity & 0 & $0.00 \%$ \\
\cline { 3 - 5 } & & Propriety & 12 & $11.88 \%$ \\
\cline { 3 - 5 } & & & & \\
\cline { 3 - 5 } & & & &
\end{tabular}




\begin{tabular}{|c|c|c|c|c|}
\hline 3 & \multirow{2}{*}{ Appreciation } & Reaction & 8 & $7.92 \%$ \\
\cline { 3 - 5 } & & composition & 1 & $0.99 \%$ \\
\cline { 3 - 5 } & & Valuation & 18 & $17.82 \%$ \\
\hline
\end{tabular}

Table 1. Attitude Occurrence Frequency

Based on the table of Attitude occurrence frequency above, the most Attitude aspect appeared is negative judgement, followed by positive appreciation and adverse affect. The following is a summary of the Attitude in konde.co regarding the ratification of the chemical castration penalty.

\subsection{The Evaluation Summary Based on the Sub-appraisal Attitude on the Text}

Based on the text description, the appraisal system, primarily the most appeared of Attitude aspect relatively is judgement, followed by appreciation and affect. The most appeared judgement on the data is negative. The assessment on this JUDGMENT aspect shows that the Government Regulation (PP) is considered unable to be a proper solution for the sexual violence case in Indonesia. In addition, the PP of chemical castration is considered inappropriate, does not answer, and cannot change the sexual violence problem in Indonesia. The PP of chemical castration is also considered inappropriate to humanity and violent human rights. In fact, the women activist strictly refuses the PP of chemical castration. In addition, there is also a positive judgment, which is the PP of chemical castration that can be populist, promoting the rights of the underprivileged.

The APPRECIATION that appears on the text is positive valuation, positive and negative reaction, and negative composition. This positive valuation relates to the other priorities considered more crucial to be handled regarding sexual violence, driving the sexual violence victims, autopsy assistance, and the regulation that can answer the sexual violence. However, the reaction aspect shows positive and negative assessments. Based on the reaction aspect, the positive evaluation refers to the ratification of the Bill on the elimination of sexual violence that is considered a concrete solution or a proper solution to overcome sexual violence. In addition, the negative evaluation shows that the Government Regulation (PP) of chemical castration is a regulation that is considered harmful, ruthless, and inhumane. The composition shows that the chemical castration penalty is not balanced with the form of the crime committed.

Affect relates to the emotions or feelings felt by the writer/speaker towards something (Martin and White, 2005). The affect aspect that appears on the data is insecurity associated with the sense of restlessness, worries, disappointment over the issuance of the PP No. 70 of 2020 regarding the implementation of chemical castration penalty for sexual violence offenders. So, the affect that appears on the data is included in the negative affect.

Based on the analysis of the Attitude aspect that appears on the text, the most frequent assessment is negative judgement. The negative evaluation of the data refers to the Government Regulation (PP) of chemical castration penalty for sexual violence offenders considered incapable and inappropriate to overcome the sexual violence problem in Indonesia. In addition, this PP of the castration can also cause a negative impact, such as exacerbating acts of sexual violence in Indonesia in the future, considered disturbing and violates one's human rights, ruthless and a bad rule. The positive evaluation is only found on the judgment aspect, which is the positive capacity, and the appreciation, which is the positive valuation and reaction. The positive evaluation refers to the potential or ability of the PP of the chemical castration penalty for sexual violence offenders in upholding the 
rights of the underprivileged. Subsequently, other priorities are considered more critical in overcoming the sexual violence problem in Indonesia, which is handling the recovery and protection of the victim. Moreover, the other things considered substantial are the provision of humane and deterrent penalties for sexual violence offenders and the ratification of the Bill on the Elimination of Sexual Violence (RUU Penghapusan Kekerasan Seksual), which is regarded as a concrete solution to resolve sexual violence in Indonesia.

\subsection{The Attitude of Konde.co towards the Government Regulation (PP) of Chemical Castration for the Sexual Violence Offenders}

Konde.co is a media that focuses on the perspective of women and minorities, which the primary concern in the violence issues and women and children's harassment, marginalization of women and minorities such as transgender, LGBT, and people with disabilities. This research focuses on the Konde.co's Attitude regarding the issues that cause pros and cons from the various parties, which is the PP ratification of chemical castration for sexual violence offenders. The Attitude analysis on Konde.co's articles regarding the PP of chemical castration shows that the most dominant Attitude that appears is negative. Therefore, Konde.co's Attitude towards the PP regarding the chemical castration for sexual violence offenders can be negative. Konde.co shows their rejection Attitudes described based on the analysis of the previous appraisal system, the emergence of judgement, appreciation, and affect which are predominantly negative in value.

Konde.co evaluate that the chemical castration penalty for sexual violence offenders is not a proper way to overcome the sexual violence problems in Indonesia, it will also exacerbate sexual crimes in the future. Konde.co agrees that the handling of this violence is more focused on the recovery of the victim's condition, and supports the legalization of the Bill on the Elimination of the Sexual Violence ( $R U U$ Penghapusan Kekerasan Seksual). Moreover, in this case, even though Konde.co shows their rejection, Konde.co also provides the other alternatives or options as suggestions and hopes to the government to handle sexual violence. Therefore, Konde.co's rejection is accompanied by their critical and solutionoriented Attitude in responding to the legalization of the Government Regulation (PP) on chemical castration for sexual violence offenders.

\section{Conclusion}

This research discusses Konde.co's Attitude regarding the ratification of the chemical castration penalty for sexual violence offenders. Based on the Attitude aspect of the clause, it is dominated by negative evaluation. The negative evaluation refers to the inappropriateness and inability of the PP on the chemical castration penalty to overcome the sexual violence problem in Indonesia. Konde.co also views PP on chemical castration for sexual violence offenders as a bad policy. The PP of this castration is also considered to have negative impacts such as extinguishing the sexual violence in Indonesia in the future, unsettling, and violating human rights. Based on the data, the positive evaluation refers to the potential and capability of the PP of the chemical castration penalty for sexual violence offenders in upholding the rights of the underprivileged. Other priorities are considered more important in overcoming the sexual violence problems in Indonesia, which is handling the recovery and protection of the victims. In addition, another solution considered more concrete in overcoming the sexual violence problems is the legalization of the Bill on the Elimination of Sexual Violence (RUU Penghapusan Kekerasan Seksual). It means that even though Konde.co shows the negative Attitude through their rejection towards the chemical 
castration penalty, Konde.co also provides another alternative and option as suggestions and hopes to the government in handling the sexual violence in Indonesia. Therefore, Konde.co's rejection is accompanied by their critical and solution-oriented Attitude in responding to the legalization of the chemical castration penalty for sexual violence offenders. Konde.co's rejection of legalization of the Government Regulation (PP) on chemical castration for sexual violence offenders is accompanied by a critical and solution-oriented Attitude.

\section{References}

Baker, P. (2010). Corpus Methods in Linguistics. In L. Litoseliti (Ed.), Research Methods in Linguistics (pp. 93-116). London: Continuum International Publishing Group.

Creswell, J. W., \& Creswell, J. D. (2018). Research Design Qualitative, Quantitative, and Mixed Methods Approaches (Fifth Edit). Los Angeles: SAGE Publication.

Dharmastuti, H. (2021). Pro-Kontra Predator Seksual Kini Bisa Dikebiri Kimia. News.Detik.Com. https://news.detik.com/berita/d-5320941/pro-kontra-predatorseksual-kini-bisa-dikebiri-kimia?single $=1$

Indrayani, S. A. (2019). Representasi Korban Pelecehan Seksual dan Resepsi Pembaca pada Berita di Media Daring [Universitas Pendidikan Indonesia]. tp://repository.upi.edu/46346/1/T_LING_1707002_Title.pdf

Kementerian PPPA. (2020). Angka Kekerasan Terhadap Anak Tinggi di Masa Pandemi, Kemen PPPA Sosialisasikan Protokol Perlindungan Anak. Kemenpppa.Go.ld. https://www.kemenpppa.go.id/index.php/page/read/29/2738/angka-kekerasanterhadap-anak-tinggi-di-masa-pandemi-kemen-pppa-sosialisasikan-protokolperlindungan-anak/

Komnas Perempuan. (2020). Lembar Fakta dan Temuan Kunci Catatan Tahunan (CATAHU) 2020. Komnasperempuan.Go.ld. https://komnasperempuan.go.id/pengumumandetail/siaran-pers-dan-lembar-fakta-komnas-perempuan/

Konde.co. (n.d.). Tentang Konde.co. Konde.Co. https://www.konde.co/tentang-kondeco/

Martin, J., \& White, P. (2005). The language of Evaluation: Appraisal in English. New York, USA: Palgrave.

Pérez, M. J. M. (2019). Exploring The Unexpected In Legal Discourse: A Corpus-Based Contrastive Analysis Of Spanish And British Judgments On Immigration. Journal of English for Specific Purposes at Tertiary Level, 7(2), 148-164.

Stosic, D. (2021). Persuasion Strategies for Demonstrating Topic Significance in Report of Randomised Controlled Trials. English for Specific Purposes, 62(2021), 1-14.

Sudaryanto. (2015). Metode dan Aneka Teknik Analisis Bahasa: Pengantar Penelitian Wahana Kebudayaan secara Linguistis. Yogyakarta: Sanata Dharma University Press.

Suprihatin, \& Lestari, R. N. (2019). Wacana Penyintas Kekerasan Seksual dalam Perspektif Kritis Tirto.Id. Jurnal Momosleca, 5(2), 114-125.

Zamzuardi, Y., \& Syahrul. (2019). Analisis Wacana Kasus Pelecehan Seksual Terhadap Perempuan pada Berita Online dalam Perspektif Analisis Sara Mills. Jurnal Dialektika, 6(1), 36-53. 